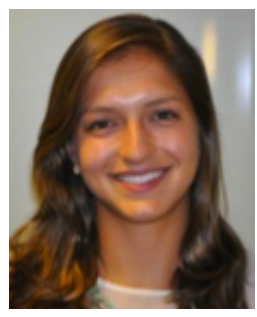

\title{
THE IMPLEMENTATION LIMITATIONS OF AND ALTERNATIVE POLICY SOLUTIONS FOR INDONESIA'S REDD + PROGRAM CONCERNING PEATLAND RESTORATION
}

\section{Sarah Guzick}

Student, Political Science

Yale University Class of 2013

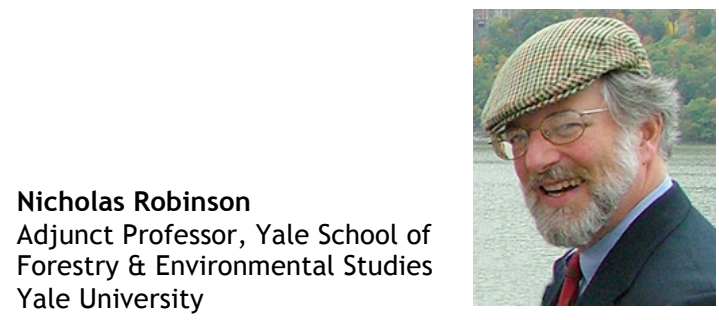

Eale School of Yale University

\begin{abstract}
Recent increases in global demand for palm oil have resulted in rapid, widespread deforestation in Indonesia, making Indonesia the third largest emitter of greenhouse gases in the world. Although the Indonesian government has sought to pursue progressive environmental policies to curb deforestation, such as through REDD+, implementation has been hampered by legal loopholes, corruption and weak rule of law. This paper will examine two alternative carbon sequestration policies to REDD+: a drying up of the palm oil market and a buy-out of palm oil plantations.
\end{abstract}

\section{Introduction}

Indonesia, the world's fourth most populous country, is an archipelago of over 17,000 islands. It possesses 50 per cent of global tropical peatlands, where layers of forest debris of up to 15,000 years old accumulate because they are too wet to decompose. These peatlands are a dual ecosystem, consisting of an acidic swamp base of perpetually submerged plants up to $15 \mathrm{~m}$ deep and tropical trees that grow on top of that swamp base. The 22 million ha of peat swamp forests in Indonesia are a storage source of carbon, sequestering in these wetlands 196 tons of carbon per ha, equivalent to 30 times as much carbon as above ground forests sequester. ${ }^{1}$ Because of these carbon stores, their role in climate change is incredibly important, because destruction of peatlands would release large amounts of carbon dioxide into the atmosphere. However, the importance of peatlands extends beyond their capacity to curb climate change. The peatlands in Indonesia are particularly important because of their location and biodiversity. Their location in the tropics enables them to absorb carbon at a faster rate than peatlands in more northern latitudes. ${ }^{2}$ They are also home to 12 per cent of all mammal species, including the endangered orangutan, 16 per cent of all reptile and amphibian species, and 17 per cent of all bird species. ${ }^{3}$

Despite the environmental value of peatlands, in the last 25 years Indonesia has continued to drain peatlands for use in agriculture and forestry. In 2008, the Guinness Book of Records named Indonesia as the country with the fastest rate of deforestation, equivalent to a loss of eight football fields of forest per minute. ${ }^{4}$ It is estimated that each year Indonesia loses 100,000 ha of peatlands as they are converted to pulp wood and palm oil plantations and rice fields, resulting in a loss of 40 per cent of total forestlands in the last 50 years. ${ }^{5}$ When the peatlands are drained, the forest debris dries and is exposed to the air, releasing methane and carbon dioxide. Massive smouldering fires across these dried peatlands are common and can burn for years, spreading smoke and ozone pollution all across the Indian Ocean region. In recent years, Indonesia has become the third largest emitter of greenhouse gases, emitting 2.5 billion metric tons in carbon dioxide equivalent annually. ${ }^{6}$ This is equal to 50 per cent of the European Union's total greenhouse gas emissions, and is only less than the emis-

\footnotetext{
Opportunity Costs of Major Land Uses in Central Sulawesi (Jakarta, Indonesia: UN-REDD Programme, July 11, 2012), 11. John Roach, 'Indonesia peat fires may fuel global warming, experts say', (2004) November National Geographic 11.

3 Indonesian Forest Facts (2011) Orangutan Foundation International <http://www.orangutan.org/rainforest/indonesianforest-facts>.

${ }^{4}$ Gunilla Wingqvist and Emelie Dahlberg, 'Indonesia Environmental and Climate Change Policy Brief' (University of Gothenberg, 8 September 2008.

5 US, RI Discuss Future of Peat Land Mangroves (14 May 2011) Waspada Online <http://waspada.co.id/index.php?option= com_content\&view=article\&id=193680:us-ri-discuss-future-of-peat-land-mangroves\&catid=30:english-news\&ltemid=101>

6 Gabriel Thoumi, Emeralds on the Equator: An Avoided Deforestation Carbon Markets Strategy Manual (MGM International, 2009) 12.
} 
sions of the much more developed nations of the United States and China. ${ }^{7}$ Eighty-five per cent of Indonesia's carbon dioxide emissions have been a result of deforestation. ${ }^{8}$

In 2007, at the $13^{\text {th }}$ Conference of the Parties to the United Nations Framework Convention on Climate Change (UNFCCC), held in Bali, policies were established to reduce such emissions from deforestation and forest degradation. These policies, collectively known as REDD (Reducing Emissions from Deforestation and forest Degradation) are meant to encourage emission reductions in developing countries through financial incentives provided by developed countries in exchange for a preservation of the carbon-rich forests of developing countries. The policies call for the involvement of many different groups, including the government and private sectors, NGOs, research institutes such as Norway's International Climate and Forest Initiative, and indigenous peoples and forest-dependent communities. ${ }^{9}$ REDD+ strategies address issues beyond deforestation and forest degradation, such as conservation, sustainable forest management, and increased carbon sequestration in forests, that must be pursued to achieve successful implementation of REDD. ${ }^{10}$ This paper will show that the protection of Indonesia's peatlands, sought under REDD and REDD+ initiatives, has not been successful because of corruption, legal loopholes and weak rule of law. It will also explore two alternative carbon sequestration policies to REDD+ as it stands now: a drying up of the palm oil market and a buy-out of palm oil plantations.

\section{Common land uses of peatlands}

Although the peatlands of Indonesia have environmental value because of their carbon storage, location and biodiversity, other economically profitable land uses have encouraged drainage and development of the peatlands. During the 1990s, Indonesian President Suharto regarded peatlands as unproductive areas prime for timber and agriculture development. After the government's aggressive pursuit to develop timber plantations in the last couple decades, the timber industry is currently in decline because of raw materials shortages and because the profitability of palm oil plantations is up to twelve-fold that of timber plantations. ${ }^{11}$

Peatlands in Indonesia were also previously converted into rice fields in an attempt to create food security for Indonesia's 240 million people. Rice accounts for more than half of the total calories in the average Indonesian diet, and Indonesia cannot produce enough to satisfy the demand. ${ }^{12}$ In 1996, the Mega Rice Project began in the Kalimantan province, with the goal being to reduce food shortages by converting one million ha of peatlands into rice paddies. ${ }^{13}$ In two years, more than $4000 \mathrm{~km}$ of irrigation canals were dug to drain the peatlands, but the canals were higher than the peatlands, so the acidic water drained out, drying out the peat. ${ }^{14}$ Thus, as the plant materials dried and were exposed to air, minerals in the soil oxidised, creating pollutants such as sulfuric acid. ${ }^{15}$ With newfound access to this land, people soon arrived to exploit the remaining timber resources, mostly through illegal logging or burning of the lands, which was the cheapest method of deforestation at the time. ${ }^{16}$ When the El Niño of 1997 caused extensive drought in the region, the fires spread beyond the land that was intended for clearing, destroying over 20 per cent of the peatlands in the province and spreading noxious smog over 15 million sq km of Southeast Asia for more than a month. ${ }^{17}$ This carbon pollution from Indonesia accounted for 13-40 per cent of mean annual carbon emissions worldwide in $1997 .{ }^{18}$

7 Sunanda Creagh, 'Indonesia Rejects Worlds Third-Largest Emitter Tag' Reuters, 23 November 2009

<http://www.reuters.com/article/2009/11/23/us-indonesia-environment-idUSTRE5AM1GQ20091123>.

${ }^{8}$ Gunilla Wingqvist and Emelie Dahlberg, 'Indonesia Environmental and Climate Change Policy Brief' (Gothenberg University, 8 September 2008), 11.

9 Stakeholder Engagement, UN REDD Programme <http://www.un-redd.org/Stakeholder_Engagement/tabid/55630/ Default.aspx.

${ }^{10}$ UN REDD Programme <http://www.un-redd.org/FAQs/tabid/586/Default.aspx>.

${ }^{11}$ Krystof Obidzinski and Ahmad Dermawan, New Round of Pulp and Paper Expansion in Indonesia: What Do We Know and What Do We Need to Know? (30 May 2011) The Center for International Forestry Research

<http://blog.cifor.org/2905/new-round-of-pulp-and-paper-expansion-in-indonesia-what-do-we-know-and-what-do-weneed-to-know/\#.UTV5megq-1k>.

${ }^{12}$ Indonesian Food Crops Country Studies <http://countrystudies.us/indonesia/66.htm>.

${ }^{13}$ Living on Earth: Public Radio International, The Indonesia Mega Rice Disaster (29 April 2011)

<http://www.loe.org/shows/segments.html?programID=11-P13-00017\&segmentID=5>.

14 'Indonesia: Environmental Profile', MongaBay.com, <http://rainforests.mongabay.com/20indonesia.htm>.

${ }^{15}$ Living on Earth: Public Radio International, above n 13.

${ }^{16} \mathrm{H}$ Boehm and F Siegert, 'Ecological Impact of the One Million Hectare Rice Project in Central Kalimantan, Indonesia, Using Remote Sensing and GIS' (Paper presented at 22nd Asian Conference on Remote Sensing, Singapore, 5 November 2001 ), 1.

${ }^{17}$ Ibid, 1.

${ }^{18}$ Simon Lord and Jason Clay, Environmental Impacts of Oil Palm: Practical Considerations in Defining Sustainability for Impacts on the Air, Land, and Water (New Britain Palm Oil LTD and World Wildlife Fund, February 2011), 8, <http://www.nbpol.com.pg/wp-content/uploads/downloads/2011/02/EnvironmentallmpactOfOilPalm.pdf>. 
According to the Indonesian government, the total losses in 1997 from the fires were US\$3.9 billion. ${ }^{19}$ The acidity and dryness of the soil intended for rice paddy development prevented the project from being completed, as 'continuous rice cultivation proved to be impossible in $90 \%$ of the planned work area' ${ }^{20}$ However, despite the failure of the Mega Rice Project and the continued lack of productivity of the planned work area, Indonesia remains the world's third largest rice producer with 37 million metric tons annually. The Minister of Agriculture, Suswono Asyraf, seeks to increase domestic production by 10 million metric tons. ${ }^{21}$

Overwhelmingly the greatest reason for conversion of peatlands has been for palm oil plantations. Indonesia recently became the world's largest producer of palm oil and has increased production over 400 per cent between 1994 and 2004, and, as of 2010, was using 8.4 million ha for palm oil plantations (see Figure 1). ${ }^{22}$ Palm oil is valuable because it is the world's highest yielding oil crop, 'with an output 5-10 times greater per hectare than other leading vegetable oils'. ${ }^{23}$ It also has historically low prices, fewer trans fats than other oils and is a part of many products, including margarine and biodiesel (which is often considered an attractive solution to fossil fuels), and is further driving the palm oil production.

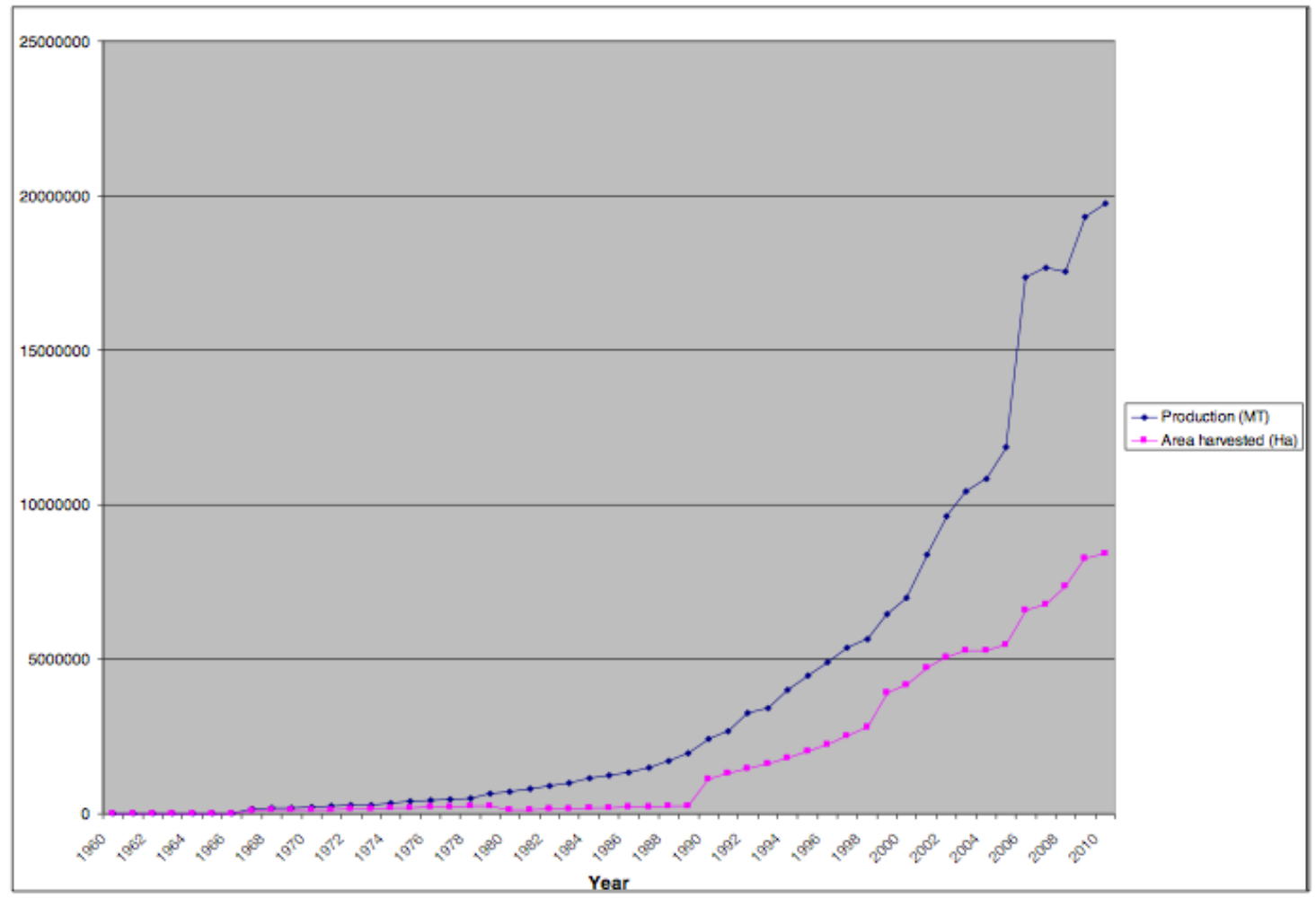

Figure 1: Oil palm harvest area (ha) and production (MT), 1960-2010. ${ }^{24}$

Palm oil plantations, as a primary land use in Indonesia, have negative environmental impacts that extend beyond deforestation and effects on climate change. They also include water and air pollution, pesticide use, lowered water tables, soil erosion and loss of habitat for endangered species such as the Sumatran orangutan, Sumatran tiger and Sumatran rhinoceros. For every metric ton of palm oil produced, 2.5 metric tons of waste is also produced. ${ }^{25}$ This waste, once processed, is usually released directly into nearby streams, leading to waterway pollution; less than 10 per cent of water in downstream areas are currently considered suitable for

\footnotetext{
19 Tropical Peat Swamp Research in Department of Forest Sciences, 'Mismanaged Peatlands: Ex-Mega Rice Project',Tropical Westlands, University of Helsinski, <http://blogs.helsinki.fi/jyjauhia/mismanaged-peatlands/>.

${ }^{21}$ Rudy Ruitenberg, 'Indonesia Wants to Boost Rice Production by 10 Million Tons, Suswono says' Bloomberg, (online), 21 January 2012 <http://www.bloomberg.com/news/2012-01-21/indonesia-seeks-10-million-ton-rice-crop-increase-suswonosays.html>.

${ }^{22}$ Ari Susanti and Paul Burgers, Oil Palm Expansion in Riau Province, Indonesia: Serving People, Planet, Profit? (European Report on Development, 2011) 12.

23 Joshua Levin, Profitability and Sustainability in Palm Oil Production (World Wildlife Foundation, March 2012 ) 13.

${ }^{24}$ Susanti and Burgers, above $\mathrm{n} 22,12$.

${ }^{25}$ World Wildlife Fund, Palm Oil and Soil and Water Pollution (2004)

<http://wwf.panda.org/what_we_do/footprint/agriculture/palm_oil/environmental_impacts/soil_water_pollution/>.
} 
human consumption. ${ }^{26}$ As palm oil plantations are developed, endangered species habitats or areas that allow exchange of genetic diversity have been destroyed, threatening the livelihood of endangered species and increasing the likelihood of human-wildlife conflicts. Biological diversity reductions from plantation establishment in forested areas have been estimated to be more than 80 per cent for plant losses, and losses of 80-90 per cent for mammals, birds and reptiles. ${ }^{27}$ Additionally, the peat and forestlands are drained as irrigation canals are built in order to expose the soil beneath, thus lowering water tables and placing the lands at increased risk of flash floods. ${ }^{28}$

The continued deforestation and degradation of peatlands in Indonesia, primarily to support the palm oil industry, can be understood as an attempt to ease the economic woes and rapid population growth the country has experienced in the last couple decades. During the Asian financial crisis of 1997-1998, caused by currency manipulation, the Indonesian economy shrank by 13.7 per cent and corruption and political instability have prevented a faster recovery. ${ }^{29}$ However, since 2007, economic growth has exceeded 6 per cent annually, but still half of Indonesia's population lives on less than US\$2 per day. ${ }^{30}$ Rapid population growth continues to be another reason for deforestation; because the growing population has a greater demand for food and natural resources, as well as produces greater pollution and waste. Food security, which Indonesia plans to achieve through self-sufficiency, has become a priority in Indonesia, where the undernourished constitute 13 per cent of the population. ${ }^{31}$ However, such a strong dependence upon rice as the staple crop makes the population incredibly vulnerable to food shortages, and many policy makers warn that the solution is not to increase rice production, as the Indonesian Department of Agriculture plans to do, but to promote diversification and increased fruit, vegetable and cash crop production, as well as trade and subsidy reform. ${ }^{32}$

\section{Recent environmental policies}

Despite the conversion of peatlands to palm oil plantations, in the last two decades Indonesia has also chosen to pursue many ambitious environmental policies, including climate change reduction, deforestation reduction, and preservation of biodiversity. In 1989, Indonesia accepted the terms of the United Nations Educational Scientific and Cultural Organisation's (UNESCO's) World Heritage Convention, under which party states are responsible for identifying natural or cultural sites that ought to be protected and preserved for the sake of national heritage. ${ }^{33}$ In 1992, Indonesia signed both the United Nations Framework Convention on Climate Change ('UNFCCC') and the Convention on Biological Diversity ('CBD'), ratifying both in 1994. The purpose of the original UNFCCC was for international powers to cooperate in limiting average global temperature increases to below two degrees Celsius and in facing climate change impacts. ${ }^{34}$ The goal of the $C B D$, which is often considered the leading document on sustainable development, is to promote conservation and sustainable use of biological diversity. ${ }^{35}$

As well as being involved in environmental initiatives on a global scale, Indonesia also has pursued initiatives within Southeast Asia. The Association of Southeast Asian Nations (ASEAN), an economic and political organisation of ten member countries including Indonesia, has also sought to address environmental challenges. Indonesia signed the ASEAN Agreement on Transboundary Haze Pollution in 2002 and has since signed the ASEAN Wildlife Enforcement Network (2005) and the Asia-Pacific Partnership on Clean Development and Climate (2005). The ASEAN organisation's environmental initiatives are evidence of their recognition that, although the ASEAN region is only three per cent of the earth's total surface, the countries within ASEAN are

\footnotetext{
${ }^{26}$ Wingqvist and Dahlberg, above $\mathrm{n} 8,3$.

${ }^{27}$ Rhett Butler, 'The Impact of Oil Palm in Borneo', MongaBay.com (online), 2009 <http://www.mongabay.com/borneo/borneo_oil_palm.html>.

${ }^{28}$ Ibid.

${ }^{29}$ Phillip Lawrence, 'Can Greece Learn from the Story of Indonesia in the Asian Financial Crisis?', The Conversation, 15 June 2012) <http: / theconversation.edu.au/can-greece-learn-from-the-story-of-indonesia-in-the-asian-financial-crisis-7513>.

${ }^{30}$ Central Intelligence Agency, Indonesia (5 February 2013) The CIA World Factbook <https://www.cia.gov/library/ publications/the-world-factbook/geos/id.html>; Elizabeth Lyons, 'AusAID Funding Reducing Food Shortages in Indonesia (4 October 2012) The Birth Pangs of New Journalism <http://elizabethnlyons.wordpress.com/2012/10/04/ausaid-fundingreducing-food-shortages-in-indonesia/>.

${ }^{31}$ OECD, 'Indonesia Can Boost Food Security Through Investment, Trade, and Subsidy Reform, Says OECD' (Media Release, 10 October 2012) <http://www.oecd.org/newsroom/indonesiacanboostfoodsecuritythroughinvestmenttradeandsubsidy reformsaysoecd.htm>.

32 Ibid.

${ }^{33}$ UNESCO, The World Heritage Convention <http://whc.unesco.org/en/convention/>.

${ }^{34}$ UNFCCC, Background on the UNFCCC: The International Response to Climate Change, United Nations Framework Convention on Climate Change <http://unfccc.int/essential_background/items/6031.php>.

${ }^{35}$ Convention on Biological Diversity (CBD), Text of the CBD, <http://www.cbd.int/convention/text>.
} 
key players in the movement to promote sustainable development and curb climate change through international and regional cooperation. In particular, ASEAN has placed an emphasis on raising domestic awareness of climate change and improving sustainable forest and peatland management, and has called upon developed countries to provide funding and technology to developing countries to aid their environmental initiatives. ${ }^{36}$ Thus, despite its status as a developing country, in the past 20 years Indonesia has sought involvement in many climate change and environmental agreements, demonstrating its desire to play a role in the global environmental scene.

Indonesia's notoriety for prioritising environmental protection particularly increased after hosting the UNFCCC $13^{\text {th }}$ Conference of the Parties in Bali in 2007, which established REDD principles meant to create a financial value for sequestered carbon and encourage green sustainable development in developing countries such as Indonesia. ${ }^{37}$ The United Nations' REDD Programme (UN-REDD) is a joint program between the United Nations Development Programme (UNDP), the Food and Agriculture Organization (FAO), and the United Nations Environment Programme (UNEP). ${ }^{38}$ The same year that Indonesia hosted the UNFCCC Conference, they also published a National Action Plan Addressing Climate Change and, in 2008, established the National Council on Climate Change. ${ }^{39}$

\section{UN-REDD Indonesia program}

During the G20 meeting in 2009, Indonesian President Susilo Bambang Yudhoyono announced that Indonesia planned to voluntarily cut the country's greenhouse gas (GHG) emissions by up to 26 per cent of the 'business as usual' scenario by 2020 , and up to 41 per cent by 2020 with the help of international aid. ${ }^{40}$ Given that Indonesia was the first developing country to combat climate change, the goal was to encourage other richer countries at the meeting to make similar promises and contribute aid to Indonesia's initiatives. ${ }^{41}$ Indonesia was then approached with an offer to participate in the UN-REDD Programme. The concept of REDD is for developed nations to provide financial incentives to developing countries to cover the costs associated with ceasing deforestation and degradation activities. The UN-REDD Programme is charged with working with countries' environmental agencies, such as Indonesia's Ministry of Forestry, to prepare countries for REDD+ readiness through methods such as 'development of national policies and stakeholder engagement', and implementation training at the provincial level, such as the launching of pilot projects in provinces. ${ }^{42}$ While the UN-REDD Programme is just one of the ways that Indonesia has sought to implement their climate change objectives and pledged responsibilities, since 2009, REDD+ initiatives, launched by both the UN and other international development organisations such as USAID and the World Bank, have been the main focus of Indonesia's environmental policy.

In May 2010, Norway responded to the call for funding, signing a Letter of Intent (Lol) pledging US\$1 billion over a period of seven to eight years based upon Indonesia's performance in addressing climate change by way of a REDD + partnership between the two countries. ${ }^{43}$ Norway's financial assistance to Indonesia is also a component of its own international commitment to mitigate climate change; the funding is part of Norway's International Climate and Forest Initiative, announced during the Bali conference. ${ }^{44}$ In return, Indonesia pledged to take 'systematic and decisive action to reduce its forest and peat related GHG emissions' by exe-

\footnotetext{
${ }^{36}$ ASEAN, ASEAN Leaders' Statement on Joint Response to Climate Change Ha Noi (9 April 2010) ASEAN Cooperation on Environment <http://environment.asean.org/asean-leaders-statement-on-joint-response-to-climate-change-ha-noi-9-april$2010 />$.

37 About REDD+, UN REDD Programme <http://www.un-redd.org/AboutREDD/tabid/102614/Default.aspx>.

${ }^{38}$ Chris Lang, Interview with Budhi Sayoko, Laksmi Banowati and Rogier Klaver: UN-REDD Indonesia:'REDD+ Is Quite A Promising Thing to Tackle Deforestation (REDD-monitor.org, 21 April 2012) <http://www.redd-monitor.org/2012/04/21/ interview-with-budhi-sayoko-laksmi-banowati-and-rogier-klaver-un-redd-indonesia-redd-is-quite-a-promising-thing-totackle-deforestation/>

39 Jessica Brown and Leo Peskett, 'Climate Finance in Indonesia: Lessons for the Future of Public Finance for Climate Change Mitigation' (Working Paper, Overseas Development Institute, February 2011), 8.

${ }^{40}$ Fidelis Satriastanti, 'Obama Addresses Climate Change in Inaugural Speech' The Jakarta Globe, 25 January 2013, <http://www.thejakartaglobe.com/blogs/obama-addresses-climate-change-in-inaugural-speech/567606>. 41 Ibid.

42 Roger Klaver, REDD+ in Indonesia (December 2012) UN REDD Programme <http: / /www.unredd.org/Newsletter35/REDD_in_Indonesia/tabid/105799/Default.aspx>.

43 Julian Caldecott et al, Indonesia-Norway REDD+ Partnership: First Evaluation of Deliverables (Gaia Consulting Ltd, 3 May 2011), 9.

44 UNEP, 'Indonesia UN-REDD National Joint Programme' (Standard Joint Programme Document, Indonesia: United Nations Environment Programme, October 2009), 6.
} 
cuting three phases of their partnership: preparation, transformation and contributions for verified emission reduction. ${ }^{45}$

In phase one of Indonesia's UN-REDD Programme, which ended in 2010, Indonesia used US\$30 million of Norway's funds to establish the National REDD+ Task Force in the President's office as the primary unit responsible for Indonesia's REDD+ agenda, and to finalise their REDD+ national strategy, a legal framework released in November of $2011 .{ }^{46}$ This involved a cooperation of UNDP Indonesia with their stakeholders: the Ministry of Forestry, the Ministry of the Environment and the National Council for Climate Change. ${ }^{47}$

During phase two of REDD Indonesia, which extends until the end of 2013, the focus, primarily executed by the UN FAO, is upon 'measurement, reporting, and verification' as well as on determining reference emission levels. ${ }^{48}$ Meanwhile, a two-year presidential moratorium on primary forest and peatland concessions has been instituted. ${ }^{49}$ The UN-REDD program selected Central Sulawesi for a pilot case in May 2010, and intends to 'build the province's capacity' by 'establishing administrative offices at the provincial and district levels' and developing policy frameworks and payment structures. ${ }^{50}$ It was chosen because it has strong local support, local capacity that is able to deliver fast results, and has easily solvable drivers of deforestation since agriculture contributes almost 40 per cent to the total economy of Central Sulawesi and employs almost 60 per cent of the population over age 15 in the province. ${ }^{51}$ The palm oil industry is also not as firmly entrenched in the social and economic livelihood of Central Sulawesi as in other regions such as Sumatra and Kalimantan because palm oil productivity is very low in this province, producing approximately six tons per ha per year compared to eight to ten tons per ha per year in Sumatra and Kalimantan. ${ }^{52}$

Meanwhile, several other provinces have been declared pilot provinces by other organisations. The government of Indonesia declared Central Kalimantan as its pilot province, to be managed by the National REDD+ Task Force and supported by the funds pledged by Norway under the Lol. ${ }^{53}$ Additionally, pilot projects were undertaken in the provinces of Aceh and West Kalimantan that seek to create community-based protection and management of forests as 'joint carbon pools'. ${ }^{54}$ For example, the NGO Fauna and Flora International (FFI), is working in West Kalimantan to assess the carbon stored in the forest areas and to compare this to the amount of carbon that would be lost if the lands were developed. ${ }^{55}$ In Aceh, the Provincial Government of Aceh has worked with FFI and the carbon brokerage firm, Carbon Conservation, to achieve the Climate, Community, and Biodiversity $(C C B)$ standard. Achievement of this standard means that the project has demonstrated that the affected local communities have agreed to the REDD+ plan and have recognised that their right to give or withhold their free, prior or informed consent had been respected. ${ }^{56}$ Bank of America then signed a pre-purchase agreement with the government of Aceh to buy future certified emission reductions at US\$4.00 per ton of avoided carbon dioxide emissions. ${ }^{57}$ This plan expects to reduce carbon dioxide emissions by 100 million tons in the next 30 years. Fifty per cent of the revenue from the pre-purchase agreement will go directly to the communities whose lands overlap with the project. ${ }^{58}$ However, despite well-delineated principles and policies, Indonesia's attempts to curb climate change under REDD and REDD+ have been poorly implemented, plagued by legal loopholes in the climate change mitigation agreements, corruption, and weak rule of law and political institutions.

\footnotetext{
${ }^{45}$ Caldecott et al, above n 43, 9.

46 Ibid 20.

${ }^{47}$ Lang, above $\mathrm{n} 38$.

48 lbid.

${ }^{49}$ Chris Lang, Indonesia's President Signs the Decree on Forest Moratorium (20 May 2011), Redd-monitor.org <http://wWw.redd-monitor.org/2011/05/20/indonesias-president-signs-the-forest-moratorium-too-little-too-late/>.

${ }^{50}$ Metta Kongphan-Apirak, UN-REDD Programme Indonesia's Pilot Province: Central Sulewesi: Questions and Answers (6 March 2012) UN-REDD <http://www.unredd.net/index.php?option=com_docman\&task=doc_download\&gid=7496\&ltemid=53>.

51 Ibid; Opportunity Costs of Major Land Uses in Central Sulawesi, above n 1, 5.

${ }^{52}$ Opportunity Costs of Major Land Uses in Central Sulawesi, above n 1, 5.

${ }^{53}$ Kongphan-Apirak, above n 50.

${ }^{54}$ UN REDD Programme, Key Results and Achievements: Indonesia <http://www.un-redd.org/Key_results_achievements Indonesia/tabid/106623/Default.aspx>.

55 Beth Askham, REDD Pilot Projects in Indonesia (20 December 2010) ECOS Magazine <http://www.ecosmagazine.com/ paper/EC10048.htm>

${ }^{56}$ Forest Peoples Programme, Aceh: The Ulu Masen REDD+ Pilot Project (Rights, Forests, and Climate Briefing Series, Jakarta, Indonesia, October 2011), 1.

57 Ibid.

58 Ibid.
} 


\section{Legal loopholes in primary climate change documents}

The Lol, REDD+ National Strategy, and the presidential moratorium each have weaknesses that have prevented successful implementation without corruption. One of the main criticisms of the Lol is that it is weakened by its lack of delineation of the rights of indigenous people. Approximately 40 million Indonesians are dependent upon forest resources for their livelihoods and therefore are directly affected by deforestation. ${ }^{59}$ While the Lol states that all UN-REDD activities that impact indigenous people should 'follow a human rights-based approach', and that indigenous people will have the 'opportunity of full and effective participation in REDD+ planning and implementation', it does not directly address land tenure challenges, which places indigenous people's livelihoods in jeopardy and threatens to harm their human rights. ${ }^{60}$ In Indonesia, less than 40 per cent of rural land holdings are titled, and it is unclear how REDD+ will handle customary tenures and whether informal property ownership by indigenous people will be respected. Recognition of customary tenures could increase the transaction costs of REDD+ and act as a disincentive for investment, as projects could be delayed or destabilised by land tenure claims and conflicts. ${ }^{61}$ In 2012, land disputes totalled 198, with at least 25 farmers shot as a result of the conflicts. ${ }^{62}$ However, it does not seem that land tenure conflicts are impeding plantation development on forestlands, as the government has been heavily criticised for ignoring rights of indigenous people and allowing land grabs by big plantation companies. In the pilot province of Central Sulawe$\mathrm{si}$, the provincial government has issued forest logging and business-use licenses without notification to the communities living in the affected areas. In justifying the provision of a 70,000 ha logging concession to a timber company, the Central Sulawesi government referred to a decree that they issued in 1992 that maintained that there was no indigenous land in the province and that 'all rights and authority over the earth and water' belonged to the state. ${ }^{63}$

Meanwhile, inconsistencies and opaque legal definitions in the National Strategy have resulted in overlapping jurisdictions, allowing for the possibility of forest conversion decisions being made according to various district governors' desires for local development and increased revenue. ${ }^{64}$ The President himself went so far as to discuss this 'serious problem in coordination and synergy between officials in central government and their local counterparts', citing this as a challenge to the climate agenda. ${ }^{65}$ More specifically, multiple criteria for forestland classifications have produced differing government maps, and subsequent enforcement of forest protections is challenged by indistinct boundary areas. ${ }^{66}$ Indonesia remains unable to identify where illegal logging is occurring, to enforce the boundaries of protected forests, or to produce one official map of these lands.

The presidential moratorium banning conversion of forests for two years, in theory, should have had considerable consequences on the palm oil and timber industries in Indonesia. However, there was no official start date given for the ban, which means that between its announcement in May 2011 and the absolute latest it could have been implemented, December 2011, many permits could have been given for forest conversions. For example, just before approving the moratorium in May, the Ministry of Forestry approved almost 2 million ha of new timber plantations on forestlands. ${ }^{67}$ To make matters worse, there are several loopholes of exemptions and exclusions that facilitate forest conversions. The moratorium does not apply to over 12.5 million ha of recently granted permits, the extension of existing permits, or 'national development' projects including geothermal, oil and gas, electricity, and rice and sugar cane production. ${ }^{68}$

\footnotetext{
${ }^{59}$ Wingqvist and Dahlberg, above $\mathrm{n} 8,6$.

${ }^{60}$ Chris Lang, Norway-Indonesia Forest Deal: US\$1 Billion Dollars Worth of Continued Deforestation? (28 May 2010), Redd monitor.org <http://www.redd-monitor.org/2010/05/28/norway-indonesia-forest-deal-us1-billion-dollars-worth-ofcontinued-deforestation/>; Central Sulawesi: UN-REDD Indonesia's Pilot Province (October 2011) Forest Peoples Programme <http://www.forestpeoples.org/sites/fpp/files/publication/2011/10/central-sulawesi-briefing-4.pdf>.

${ }^{61}$ Ahmad Dermawan, Elena Petkova, Anna Sinaga, Mumu Muhajir and Yayan Indriatmoko, 'Preventing the Risk of Corruption in REDD+ in Indonesia' (Working Paper, Center for International Forestry Research, 2011) 15.

${ }^{62}$ Willy Masaharu, 'Local People Must Benefit, Minister Says', The Jakarta Globe (online), 21 January 2013, <http://www.thejakartaglobe.com/nvironment/local-people-must-benefit-minister-says/566631>.

${ }^{63}$ Central Sulawesi: UN-REDD Indonesia's Pilot Province (October 2011) Forest Peoples Programme <http://www.forestpeoples.org/sites/fpp/files/publication/2011/10/central-sulawesi-briefing-f.pdf>.

${ }^{64}$ Dermawan et al, above $\mathrm{n} 61,14$.

${ }^{65}$ Nani Afrida, 'President Calls for Better Synergy to Meet Climate Change Targets' The Jakarta Post (online), 1 October 2011, <http://www.thejakartapost.com/news/2011/10/01/president-calls-better-synergy-meet-climate-change-targets.html>.

${ }^{66}$ Chris Lang, Interview with Kuntoro Mangkusubroto, Head of Indonesia of Indonesia's REDD+ Task Force (Interview, 20 September 2012) Redd-monitor.org <http://www.redd-monitor.org/2012/09/20/interview-with-kuntoro-mangkusubroto/>.

${ }^{67}$ Obidzinski and Dermawan, above $\mathrm{n} 11$.

${ }^{68}$ Lang, above $\mathrm{n} 49$.
} 


\section{Weak rule of law}

The loopholes, lack of specifications, and inconsistencies in these three important climate change policy documents serve to highlight the weak rule of law in Indonesia. For example, the President was pressured into only protecting primary forests in his moratorium, instead of also protecting secondary forests. Secondary forests, which are forests that have re-grown after disturbances such as fire or timber harvesting, are important to climate change because they are significant carbon sinks, sequestering 155-170 tons of carbon per ha, compared to 40 tons of carbon per ha for palm oil plantations and 196 tons of carbon per ha for primary forests (see Figure 2). ${ }^{69}$ Purnomo, President Yudhoyono's special advisor on climate change, reassured the palm oil industry that 'there is no limitation for those who want to develop business-based plantations ... we are just advising them to do so on secondary forests'. ${ }^{70}$

\begin{tabular}{|l|r|l|}
\hline \multicolumn{1}{|c|}{ Land Cover Type } & $\begin{array}{c}\text { Carbon Stock } \\
\text { (tC per ha) }\end{array}$ & \multicolumn{1}{c|}{ Reference/ Assumptions } \\
\hline Primary Forest & 195.4 & TSP/PSP NFI -MoFor \\
\hline Secondary Forest & 169.7 & TSP/PSP NFI -MoFor \\
\hline Primary Mangrove Forest & 170 & BAPPENAS Study, 2010 \\
\hline Primary Peat Forest & 196 & Based on IFCA Study (MoFor, 2008) \\
\hline Secondary Mangrove Forest & 120 & Komiyama, 1998 in (BAPPENAS Study, 2010) \\
\hline Secondary Peat Forest & 155 & Based on IFCA Study (MoFor, 2008) \\
\hline Forest Plantation & 100 & Ditjenplan, MoFor \\
\hline Shrub & 15 & Wasrin, 2000 in (BAPPENAS Study, 2010) \\
\hline Swamp Shrub & 15 & Ditjenplan, MoFor \\
\hline Agriculture Plantation & 63 & Rogi (2002); Palm et al. (2004); IPCC (2006) \\
\hline \multicolumn{1}{|c|}{ Cocoa } & 29.3 & Yuliasmara, 2008 in (ICRAF Study, 2010) \\
\hline Coconut & 30.7 & FAO, 1997 \\
\hline \multicolumn{1}{|c|}{ Palm oil } & 40 & ICRAF Study (2010) \\
\hline Settlement & 1 & Ditjenplan, MoFor \\
\hline Bare Land & 0 & Ditjenplan, MoFor \\
\hline Grassland & 4.5 & Ditjenplan, MoFor \\
\hline Annual Crop Agriculture & 8 & Ditjenplan, MoFor \\
\hline Agriculture Land (agroforestry) & 10 & Ditjenplan, MoFor \\
\hline
\end{tabular}

Figure 2: Above-ground biomass of various land use systems in Indonesia ${ }^{71}$

Another weakness of Indonesian political institutions is evidenced by the fact that the REDD+ Task Force is under the Office of the President. After the first Task Force expired in June of 2011, President Yuhhoyono announced the establishment of a second Task Force, reporting directly to the President. ${ }^{72}$ While Yudhoyono's commitment to curbing climate change is admirable, the positioning of the group within the Office of the President makes it difficult for the group to pursue policies in a direction other than the direction preferred by the President. When presidential elections occur in 2014, the working group will be vulnerable to the political opinions of the new president. A point worth noting is that the majority of political campaign financing comes from the palm oil and pulp wood industries. ${ }^{73}$ REDD+ will not be functional if the new President favours the agriculture industry or does not support the development of a robust REDD+ agency that is not under his thumb.

\footnotetext{
${ }^{69}$ Opportunity Costs of Major Land Uses in Central Sulawesi, above n 1, 11.

${ }^{70}$ Lang, above n 49.

${ }^{71}$ Opportunity Costs of Major Land Uses in Central Sulawesi, above n 1, 11

72 Leony Aurora and Catriona Moss, 'Indonesian President Forms New REDD+ Task Force' on CIFOR Forests News Blog (13 September 2011) <http://blog.cifor.org/4144/indonesian-president-forms-new-redd-task-force/\#.UYXOmII8y3k>.

${ }^{73}$ Wimar Witoelar, 'Insight: Yudhoyono's Robust Response to Climate Change', The Jakarta Post (online), 7 November 2012 <http://www.thejakartapost.com/news/2012/11/07/insight-yudhoyono-s-robust-response-climate-change.html>.
} 


\section{Corruption}

One issue - and arguably the biggest challenge to carbon sequestration in Indonesia - that results from weak political institutions is the prevalence of corruption. Because of a lack of uniform mapping of forestlands, it is difficult to determine whether or not permits are legitimate, resulting in the forestry sector being renowned for its corruption. In 2009, Legislator Al Amin Nasution received an eight-year prison sentence after being found guilty of accepting bribes to grant the approval of a forest conversion on Bintan Island in Riau. ${ }^{74}$ In just the first three months after the moratorium was announced in May 2011, it was found that there were 103 clearings in forestlands protected under the moratorium, and still 40 per cent of timber production remains illegal. ${ }^{75} \mathrm{~A}$ forestry official who negotiated the partnership with Norway is a suspect in 'a multi-million dollar corruption case', naturally leading one to question whether Norway's money will be properly managed. ${ }^{76}$ Another instance of corruption occurred in August 2011, three months after the signing of the moratorium, when Aceh's then governor, Irwandi Yusuf, signed a permit allowing palm oil company, PT Kallista Alam, to convert 1605 ha of forest in the Tripa Peat Swamp into a palm oil plantation. ${ }^{77}$ When the moratorium map was revised six months later, this concession area was no longer listed as a protected area under the moratorium. ${ }^{78}$ Meanwhile, by August of 2012, the Forestry Ministry had approved permits converting more than 300,000 ha of forests that year, putting them on track to exceed total concession areas for the two previous years. ${ }^{79}$ Once the Forestry Ministry has given a permit, land management is under the jurisdiction of the National Land Agency (BPN), which has consistently scored below the Indonesian Corruption Eradication Commission's standard of integrity in its Public Sector Integrity Survey. ${ }^{80}$

\section{First step forward: An education campaign}

The conclusion that can be taken from Indonesia's struggles to enforce protection of their forests and peatlands is that the national authorities are not fully motivated to curb climate change if it means harming their economic growth or influential agriculture and timber industries. For the REDD+ partnership with Norway to be successful and for Indonesia to receive more international aid for their climate change initiatives, they need to stop approving permits despite the presidential moratorium. They need to build a stronger political institution that is in charge of the climate change agenda, instead of an office under the President's thumb. It is worth pointing out that the only resistance to forest protections is from the industries that want to develop on forestlands. There is no mainstream resistance to the initiatives, which only serves to further highlight the lack of power and motivation to prioritise climate change protections over industry interests.

One of Indonesia's first goals in moving forward should be to educate their elite decision makers as well as their working classes. Some of these elites may continue to favour industry interests, such as Aceh Governor, Zaini Abdullah, who recently submitted spatial zoning proposals that would allow logging on 52,000 ha of protected forests. ${ }^{81}$ However, it is often a lack of knowledge that leads to the harmful deforestation. While all are aware that logging and development of plantations in protected forests are illegal activities, they are often unaware of the global climate change consequences of their actions. An education program needs to be implemented that involves every Indonesian, so that they are motivated to protect their forest lands and also hold their policy makers accountable for doing so. Eighty-seven per cent of Indonesians are Muslims, and the Qur'an asserts that everyone has a duty to 'follow the nature designed by Allah' and not to alter the creation of Allah. ${ }^{82}$ Three central concepts of Islam, Tawhid, Khalifah and Akhirah, or unity, trusteeship and accountability,

\footnotetext{
${ }^{74}$ Ina Parlina, 'Corruption in Land Sector Involves "Many Actors"', The Jakarta Post (online), 4 March 2011 $<$ http://groups.yahoo.com/group/batavia-news/message/11388>.

${ }^{75}$ Kemen Austin, Stuart Sheppard and Fred Stolle, Indonesia Stmoratorium on New Forest Concessions: Key Findings and Next Steps (World Resources Institute, 2012), 4.

${ }^{76}$ Creagh, above $\mathrm{n} 7$.

${ }^{77}$ Chris Lang, 'Indonesia Court Revokes Oil Palm Concession in Tripa Peat Swamp' (7 September 2012) Redd-monitor.org <http://www.redd-monitor.org/2012/09/07/indonesian-court-revokes-oil-palm-concession-in-tripa-peat-swamp/>.

${ }^{79}$ Fidelis Satriastanti and Arientha Primanita, 'Permits for Conversion of Forest to Plantations on Track to Top Past 2 Years', The Jakarta Globe (online), 9 August 2012 <http://www.thejakartaglobe.com/news/permits-for-conversion-of-forest-toplantations-on-track-to-top-past-2-years/536686>.

80 Parlina, above $n 74$.

${ }^{81}$ Hayat Indriyatno, 'Aceh Governor Wants to Allow More Logging in Protected Forests: Report', The Jakarta Globe (online), 13 February 2013 <http://www.thejakartaglobe.com/news/aceh-governor-wants-to-allow-more-logging-in-protected-forestsreport/571446>

82 'Islamic Belief About the Environment', BBC News <http://www.bbc.co.uk/schools/gcsebitesize/rs/ environment/isstewardshiprev1.shtml>.
} 
could be applied to environmental ethics in an educational campaign to promote peatland conversation and protection of biodiversity. ${ }^{83}$

Many Indonesians may be unaware that their biodiversity is actually the richest in the world, even greater than Brazil's Amazon rainforests. ${ }^{84}$ However, due to their poor land use and development policies, they also have the largest number of endangered vertebrate species. ${ }^{85}$ Indonesia is party to the UN Convention on Biological Diversity ('CBD') and pledged to set aside as conservation areas 200,000 sq km of coastal and marine habitats by $2012 .{ }^{86}$ The public interest in such activities, as well as conservation of forest and peatlands, could be the face of an educational campaign that connects the CBD and REDD+ pledges made by the Indonesian government. The campaign could even draw connections to Indonesia's duty under the UNESCO World Heritage Convention to identify and protect its unique sites of national and cultural heritage, such as peatlands and areas of great biodiversity, for the sake of humankind throughout the world. By encouraging Indonesians to protect their biodiversity in order to remain the most bio-diverse country in the world, the educational campaign could foster price and respect for Indonesians' domestic environment while protecting the global environment in the process.

However, if Indonesia is going to take decisive action to combat climate change in the next few years, when it is most needed, an educational campaign will not be enough; a drastic change in economic strategy and policy is also necessary. Two potential avenues stand out: a drying up of the international palm oil market by major importers China, India and the European Union (EU) ceasing imports, or using international funds to buy back the plantation lands and re-wet the peat.

\section{Limiting the international market for palm oil}

The first of these, limiting the international palm oil market for Indonesian palm oil, is important since Indonesia exports 70 per cent of their palm oil. ${ }^{87}$ In 2012, China, the EU and India accounted for 49 per cent of total global palm oil imports (see Figure 3 ). ${ }^{88}$ In order to dry up the international market, importing countries would need to establish either a ban or place a low quota on palm oil imports, or to establish sustainable energy initiatives under which palm oil-based biodiesel does not qualify as a sustainable fuel. Both the EU and the US have recently established sustainable energy initiatives that affect their demand for palm oil, but these policy changes will not decrease palm oil imports as hoped.

A strong driver of palm oil demand recently has been the EU Renewable Energy Directive ('RED'), which started in late 2010. There are three binding, unilateral climate targets for 2020: a 20 per cent reduction in GHG emissions below 1990 levels, a 20 per cent reduction in energy use from 1990 levels by improving energy efficiency, and renewable energy comprising 20 per cent of total energy consumed.$^{89}$ RED also set a target of 10 per cent for renewable fuels, such as biofuels, in the transportation sector by $2020 .^{90}$ Although $R E D$ is meant to create GHG emission savings while conserving biodiversity by ensuring that biofuels do not come from drained forests and peatlands, in practice it has not been able to make this distinction between sustainable and destructive palm oil production, thus increasing demand for Indonesian palm oil and encouraging increased deforestation. This is because the RED does not regulate the sustainability of land or water resources used during the production process; it simply regulates the sustainability of the final product, according to criteria set out by the Roundtable on Sustainable Palm Oil (RSPO). RSPO, while purportedly prioritising 'certified sustainable' palm oil, does not have the capacity to verify that 'certified sustainable' palm oil was not produced on drained wetlands or burned forests, and also openly accepts palm oil from plantations on secondary forests and peatlands. ${ }^{91}$ Only approximately 14 per cent of the total oil palm plantation area in Indonesian is certified by RSPO. ${ }^{92}$ While the EU may be able to slightly improve the sustainability of their palm oil imports by hand-

\footnotetext{
${ }^{83}$ Ibid.

84 Jatna Supriatna, 'Int'l Year of Biodiversity and Indonesia', The Jakarta Post (online), 23 January 2010

<http://www.thejakartapost.com/news/2010/01/23/int039l-year-biodiversity-and-indonesia.html>.

${ }^{85}$ Ibid.

86 Ibid.

${ }^{87}$ Frank Gunstone, Palm Oil in the Market Place, (March 2012) AOCS Lipid Library,

<http://lipidlibrary.aocs.org/market/palmoil.htm>.

${ }^{88}$ Top Ten Palm Oil Importers 2012 (22 November 2012) Agriculture Corner <http://www.agricorner.com/top-ten-palm-oilimporters-2012/>.

89 'The Malaysian Palm Oil Sector - Overview' (European Union Delegation to Malaysia, June 2012) 16.

${ }^{90}$ Ibid.

91 'EU palm Oil Approval Threatens Indonesia's Forests, NGOs Says', EurActiv.com (online) 7 December 2012

<http://www.euractiv.com/energy/commission-decision-palm-oil-sus-news-516445>.

${ }^{92}$ Susanti and Burgers, above $\mathrm{n} 22,23$.
} 
picking sources of supply with the fewest doubts about their sustainability index, there will be increased overall demand for palm oil-based biodiesels as countries reduce dependence upon fossil fuel use. Thus, palm oil that has not been verified by RSPO, coming from plantations built on protected forests and peatlands, will also easily be able to find a market for their product.

\section{Palm Oil World Imports}

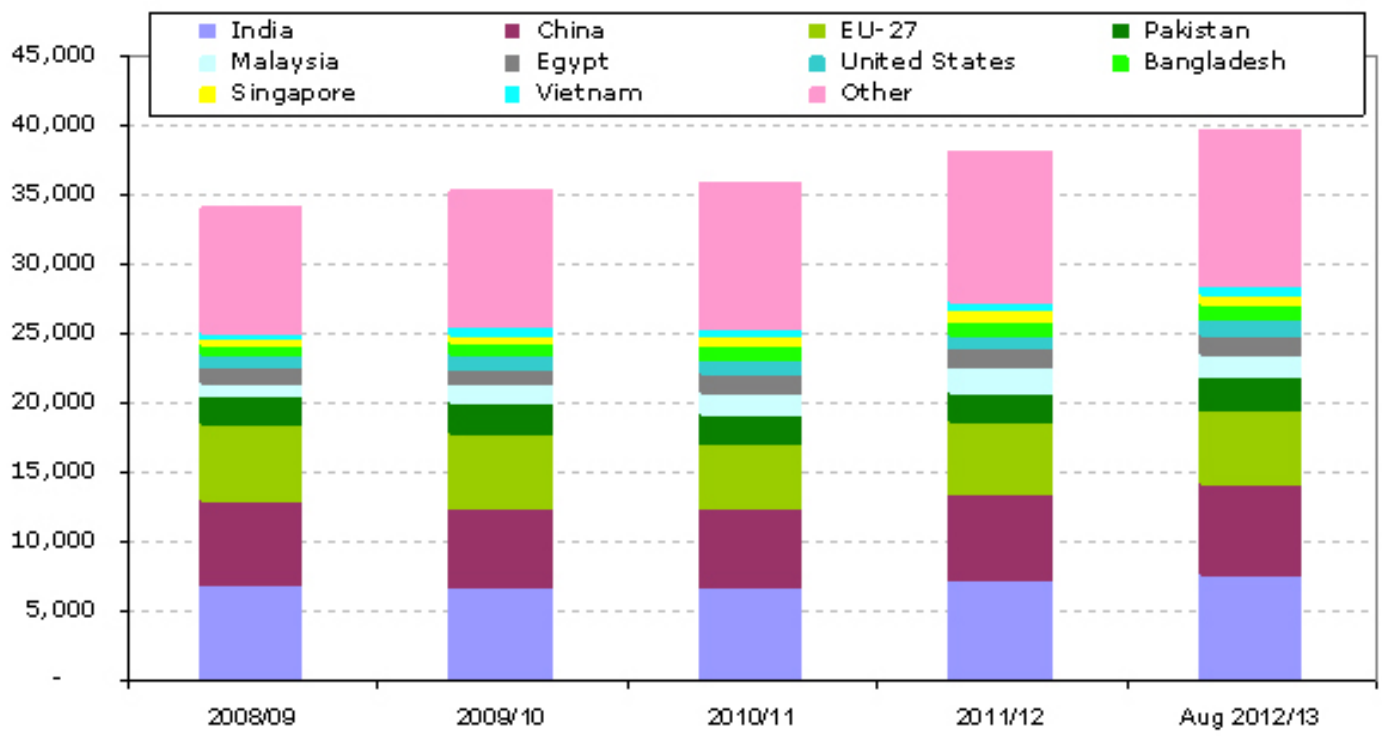

Figure 3: Palm oil world imports ${ }^{93}$

The palm oil industry is not just benefited by RED because the RSPO criteria are weak and not thoroughly enforced, it also benefits from being declared compliant with the EU's policy because other crop-based biodiesels are not accepted under the RED, giving palm oil an advantage over their main competitors soybean and rapeseed oil. Since the EU plans to double its use of crop-based biofuels by 2020, according to the RED, palm oil plantations will be gifted with ever-increasing demand, making conversion of Indonesian peatlands into plantations seem more enticing by the day. ${ }^{94}$ Not surprisingly, last year, Indonesian palm oil production increased 8.11 per cent and exports grew by 9.5 per cent, as EU palm oil imports grew by 12.09 per cent. $^{95}$

The US initially took a harsher stance on palm oil but earlier this year re-opened the domestic market to palm oil imports from abroad. In late 2012, the US Environmental Protection Agency (EPA) found that palm oil-based biodiesel does not meet the minimum 20 per cent lifecycle GHG reduction threshold required to qualify as a renewable under the Renewable Fuel Standard (RFS) program. ${ }^{96}$ However, in early 2013, the US Congress revived a prior $\$ 1$ per gallon tax credit for alternative fuels, under which palm oil qualifies, as an attempt to avoid the 'fiscal cliff'. In economic terms, this means that the US can import palm-based biodiesel at $\$ 1100$ per ton including shipping costs, compared to domestically produced soybean oil-based biodiesel that costs approximately $\$ 1200$ per ton. ${ }^{97}$ Palm oil traders in Indonesia have already seen large increases in exports to the US this year. ${ }^{98}$

In addition to the EU and US encouraging palm oil production and thus deforestation in countries like Indonesia that have low governance capacity to properly enforce sustainability criteria, India and China have increased demand in recent years without even suggesting sustainability considerations. India consumed 15 per cent of global palm oil production in 2011 , and 80 per cent of those imports were imported from Indonesia. ${ }^{99}$ Despite

\footnotetext{
93 Ibid.

94 Rhett Butler, 'EU OKs Biofuels Produced from Certified Palm oil', MongaBay.com (online), 28 November 2012 <http://news.mongabay.com/2012/1128-rspo-palm-oil-ok-in-eu.html>

95 Indonesia Palm Oil Production by Year (1000 MT) (IndexMundi, 8 March 2013),

<http: / / www.indexmundi.com/agriculture/?country=id\&commodity=palm-oil\&graph=production>.

96 The Malaysian Palm Oil Sector, above n 90, 17.

97 'SE Asian Palm Oil Producers Target US Biofuel Market', The Star Online, 4 March 2013

<http: / / biz.thestar.com.my/news/story.asp?file=/2013/3/4/business/20130304163909\&sec=business > .

98 'US Blending Credit for Alternative Fuels Encourages Palm Oil Imports', Trade and Environment Newletter (online), March 2013 <http: / /worldgrowth.org/2013/03/trade-and-environment-newsletter-issue-18-march-2013/>.

99 Agence France-Presse, 'Palm Oil for India "Destroying Indonesian Forests"' (19 June 2012) Mother Nature Network, <http://www.mnn.com/earth-matters/wilderness-resources/stories/palm-oil-for-india-destroying-indonesian-forests>.
} 
an economic downturn last year, China is expected to increase demand for palm oil by 16 per cent by the end of 2013. ${ }^{100}$ Although China tightened quality control on imports at the beginning of this year by requiring that edible oils be of 'landed quality' with no deterioration having occurred during shipping process, they have yet to address the issues of sustainability or climate change related to palm oil trade.

One of the primary difficulties with decreasing imports from countries like India, China and Pakistan (the fourth greatest importer) is that these countries use the oil for cooking processes instead of as a biofuel input. Thus, a sustainable biofuel initiative will not significantly impact demand for palm oil in those countries. Additionally, a recent economic study examining the price and income elasticity of Indonesian palm oil found that consumers prefer palm oil to soybean oil, and that soybean oil prices do not significantly determine the quantity of palm oil that Indonesia exports in both the short- and long-run. ${ }^{101}$ Thus, finding potential substitutes to palm oil to use as a cooking oil may be more difficult than originally expected.

While setting strict national renewable fuel initiatives and ensuring that palm oil is not able to slip into the initiatives as a crop-based renewable may be one way to decrease global demand, the palm oil traders will inevitably continue to be a big player in the cooking oil market and possibly find other markets for their product. Black markets will arise in some developing countries that do not have the capacity to enforce sustainability criteria, and other developing countries may simply be unwilling to commit to sustainability initiatives without receiving financial support from large developed nations, which would then resemble the monetary flow of the REDD scheme.

\section{A buy-out scheme}

The second strategic overhaul, a buy-out scheme, is the preferred course of action because it does not depend upon cutting demand but instead focuses upon cutting supply. Essentially, international funds could be used to buy back the peatlands that palm oil companies built their plantations on. Alternatively, the international funds would be used to pay the poor workers to relocate and to re-wet the peat, and a hefty tax would be levied on use of peatlands for palm oil production so that production was no longer profitable. First, to better illustrate what a buy-out scheme using a domestic policy and education campaign backed by international funds would look like, it is worthwhile to explore Scotland's recent peatland restoration program.

\section{Case study}

In the far north of Scotland lies Flow Country, which has 1500 square miles of blanket bog, or peatland of variable depth, that has developed over undulating ground. The peatland dates from the last Ice Age over 10,000 years ago. In the 1970s and 1980s, non-native conifer trees were planted to develop Scotland's forestry industry. ${ }^{102}$ The conifer trees also served as a tax loophole for the rich, as they could write-off investment in the forestry area from their personal income tax, until the loophole was closed in $1988 .{ }^{103}$ Flora and fauna in the area lost much of their diversity, but the larger issue has been the loss of sequestered carbon. As the roots of the conifers penetrated the peat of the bog, they dried out the peat, which then oxidised, thus releasing carbon. ${ }^{104}$ Since only a five per cent reduction of stored carbon would equal the United Kingdom's (UK) total annual GHG emissions, the carbon loss greatly increased the UK's emissions during that time. ${ }^{105}$

In 1988, the Royal Society for the Protection of Birds and the Nature Conservancy Council campaigned to protect the Flow Country, and Sites of Special Scientific Interest (SSSIs) were established. ${ }^{106}$ In 1992, the Peatland Management Scheme was started, and in 2001, a £2.8 million joint project between conservationists and foresters was started to restore damaged blanket bogs in the area. ${ }^{107}$ Then in 2012, a campaign called Flow to the Future was started to restore a specific seven square mile area of Flow Country to its peatland conditions. ${ }^{108}$

\footnotetext{
100 Yoga Rusmana, 'Palm Oil Seen Rising 16\% by Year-End as China, India Recover', Bloomberg (online), 8 February 2013, <http: / / www.bloomberg.com/news/2013-02-07/palm-oil-seen-advancing-16-by-year-end-as-china-india-recover.html>.

101 Ambiyah Abdullah, 'Determinants of Indonesian Palm Oil Export: Price and Income Elasticity Estimation' (2011) 5 Trends in Agricultural Economics 52.

102 'Boost for Flow Country Peatland Restoration', Heritage Lottery Fund (online), 10 November 2012 <http://www.hlf.org.uk/news/Pages/HeritageLotteryFundgoeswithTheFlow.aspx>.

${ }^{103}$ David Ross, 'Funding Milestone in $\mathrm{E} 4 \mathrm{~m}$ Plan to Restore Peatlands', Herald Scotland (online), 11 October 2012 <http: / / www.heraldscotland.com/news/home-news/funding-milestone-in-4m-plan-to-restore-peatlands. 19115728>.

${ }^{104}$ Bringing Life Back to the Bogs (The Royal Society for the Protection of Birds, 2012) 9.

105 Boost for Flow Country Peatland Restoration, above n 102.

${ }^{106}$ Bringing Life Back to the Bogs, above n 104, 9.

107 Ibid 11.

108 Boost for Flow Country Peatland Restoration, above n 102.
} 
The project applied for a financial grant of $£ 4$ million from the Heritage Lottery Fund (HLF), and has passed the first round of the application, thus receiving $£ 147,000$ for initial development funding. ${ }^{109}$ Also aided by $£ 1.7$ million from the Scottish government, Flow to the Future plans to let the water level rise in the area to bring back the peat, and the project is expected to double the carbon stored in all of the UK's forests. ${ }^{110}$ Flow to the Future is part of the larger International Union for the Conservation of Nature (IUCN) UK Peatland Programme, which seeks to restore 1 million ha of peatlands in the UK by $2020 .^{111}$

\section{Indonesian peatland restoration}

To execute a buy-out for Indonesian peatlands, international powers need to be on board, and they need to be convinced that the scheme will work. While Scotland may be a successful example, an intervention in a developing country will be very different, but perhaps easier in a couple ways. There will be little political resistance within the country to the buy-out, as climate change has been talked about recently in Indonesian environmental policy but not yet successfully addressed. The primary source of expected resistance is from the palm oil industry itself, but only the white-collar workers and plantation owners, with additional resistance being expressed by the Government, resulting from a fear of decreasing revenues. As mentioned earlier, elite decision makers need to be educated about the benefits of the buy-out. Butler and Conway demonstrated that, in Central Kalimantan, preservation of peatlands for their carbon value (engagement in a carbon credits market) is more economically profitable than using the land to produce palm oil based upon 2007 carbon prices in carbon markets. ${ }^{112}$ Meanwhile, the media front should be a domestic policy campaign, with a focus upon preservation of biodiversity and possibly ecotourism, and a goal to foster pride and commitment from the general population, so that people feel as though it is their privilege to protect their peatlands. Given that, in Indonesia, the prevailing ideology of formal land tenure is that the government owns natural resources, a buyout program simply resembles implementation of national sovereignty. Certain aspects of such a scheme need further detailing, including institution of a tax on the peatlands used for palm oil production, examination of expected economic costs and environmental and social impacts of the project.

The economics of the buy-out could be formulated in two different ways. In order to obtain the land, international funds could be used to buy the plantation lands from palm oil companies. Alternatively, the Indonesian government could tax the production of palm oil as a land use so heavily that palm oil production is no longer profitable and the palm oil companies would seek to sell the lands. In either scenario, the carbon value of the lands needs to produce revenue as carbon credits in an international market, and financial aid needs to be provided for worker relocation and re-wetting of the peat. It is important to note that 91 per cent of all palm oil plantation areas are located in Sumatra or Kalimantan (see Figure 4). ${ }^{113}$ This means that the other provinces see little of the palm oil industry profits, but do have a stake in the future value of the forest.

Figure 4: Location of oil palm plantation (ha) in Indonesia in 2009 (estimation) ${ }^{114}$

Location of oil palm plantation (ha) in Indonesia in 2009 (estimation)

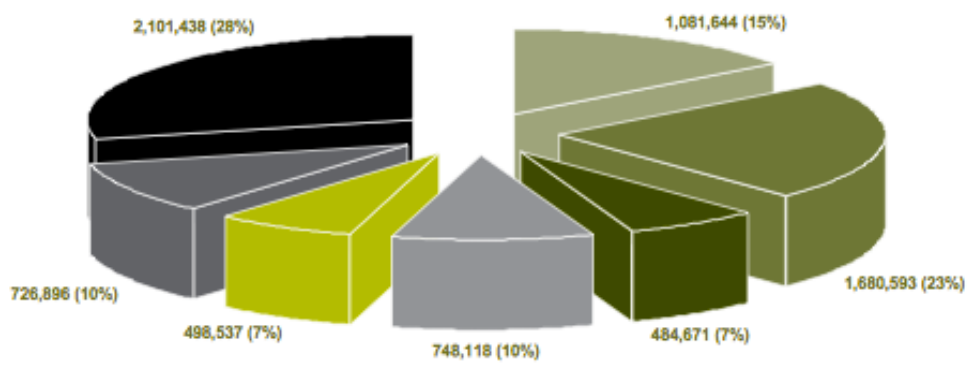

\author{
Riau \\ North Sumatra \\ - South Sumatra \\ - Central Kalimantan \\ West Kalimantan \\ - Jambi \\ - Others \\ (below 480.000ha each)
}

Source (raw data) :

Directorate General of Estate Crops

\footnotetext{
109 'Lottery Boost for Flow Country Peatland Restoration', BBC News, 11 October 2012 <http://www.bbc.co.uk/news/ukscotland-highlands-islands-19883344>.

${ }^{110}$ Ross, above n 103.

111 UK Peatland Restoration - Demonstrating Success (Edinburgh: IUCN UK National Committee Peatland Programme, June 2012) 2.

112 Rhett Butler and Sarah Conway, 'Could Peatlands Conservation Be Profitable?', The Jakarta Post (online), 22 August 2007, <http://www.tmcnet.com/usubmit/2007/08/22/2881681.htm>.

${ }^{113}$ Buntoro Rianto, Palm Oil Plantation: Industry Landscape, Regulatory and Financial Overview (PricewaterhouseCoopers, 2010) 2. 
In a study done in the UN-REDD pilot province of Central Sulawesi, palm oil plantations were found to have the greatest profitability of many land uses, including logging, cacao, coconut and rice production, despite having much lower productivity than palm oil plantations in Sumatra and Kalimantan islands. ${ }^{115}$ Palm oil plantations earned approximately 72 million IDR (Indonesian rupiahs) per ha per year, or approximately US\$7416 per ha per year. ${ }^{116}$ In 2008, Indonesia exported over US\$14.5 billion in palm oil-related products. ${ }^{117}$ It is unlikely that direct payments of international funds to palm oil companies would convince them to sell the land on which they have so much expected future profitability, and it is also unlikely that the international community would be able to collectively contribute such vast amounts of money.

Thus, it is clear that the next strategy, taxation, is the preferable mechanism of executing the land ownership change involved in the buy-out scheme. This taxation is preferable to the direct payments because it involves demanding payments from the palm oil industry instead of providing them with large sums of money to move from their lands. Current taxes on palm oil companies in Indonesia include export taxes, corporation income taxes, property taxes and value added taxes, and usually generate approximately US\$495,000 per year. ${ }^{118}$ One caveat of a taxation scheme is that over 90 per cent of Indonesian palm oil plantations already underpay their taxes and, with the weak rule of law and corruption previously discussed, strict enforcement of greatly increased taxes could be challenging for the government to implement. ${ }^{119}$ In order to calculate the additional taxes that must be levied about palm oil producers, it is necessary to determine the opportunity costs and the transaction costs that would accompany a buy-out scheme. The opportunity costs are the foregone after-tax profits that would result from the land being used to produce palm oil (US\$7416 per ha per year), and the transaction costs include all costs associated with 'establishing and running the scheme' and the costs landowners must pay to participate in the project. ${ }^{120}$ Although actual tax increases cannot be calculated because information is limited, a bare-bones calculation concludes that essentially taxes must be increased enough so that tax revenue is greater than or equal to the annual profits of US\$7416 per ha. This tax estimate is much higher than what would likely be necessary to render palm oil production unprofitable because it does not take into account the impacts of financial aid for relocation of plantation workers, or the revenues resulting from the carbon value of the conserved lands being traded in international carbon markets.

The second step of the buy-out scheme, in addition to obtaining ownership of the plantation lands from the palm oil industry, involves provision of financial aid to workers to relocate. There are 3.7 million people in Indonesia who are involved in the palm oil industry and downstream industries. ${ }^{121}$ The palm oil industry is very labour-intensive, with five workers per ha, compared to an average of one worker per ha for other oil crops. ${ }^{122}$ The rapid increase in demand for palm oil has increased the need for skilled labourers, but such workers are limited. In terms of job security, there is a distinction between casual workers and permanent, contracted workers on palm oil plantations. Casual workers make US\$50-150 per month, which does not cover their fundamental monthly needs and places them below the poverty line of US\$213 per month, and permanent workers, who make closer to US\$250 per month, still barely above the poverty line. ${ }^{123}$ Increasingly, plantations have been hiring more casual workers and giving them fewer benefits instead of hiring permanent workers who live on the plantation and earn benefits. ${ }^{124}$ Usually, only men are contracted permanent workers and their families often must resort to working on the plantations also, as casual workers. ${ }^{125}$ While studies have often found that palm oil plantations promote economic development by providing revenue to the states and employment to rural villagers, the economic and social impacts on small rural communities are not always positive. In a study carried out on the development of a palm oil plantation in West Kalimantan, more than half of the rural residents who lost their lands to the plantation reported a decline in their livelihood as income from forest materials decreased. ${ }^{126}$ Those who indicated livelihood improvements were smallholder palm oil

\footnotetext{
${ }^{115}$ Opportunity Costs of Major Land Uses in Central Sulawesi, above n 1, 18.

116 Ibid.

117 Palm Oil Green Development Campaign, The Economic Benefit of Palm Oil to Indonesia, (WorldGrowth, February 2011 ), 11.

${ }^{118}$ Facts of Indonesian Palm Oil (Indonesia Palm Oil Advocacy Team, 2010) 3.

119 Butler and Conway, above n 112.

${ }^{120}$ Opportunity Costs of Major Land Uses in Central Sulawesi, above n 1, 3.

${ }^{121}$ Levin, above n 23, 4.

122 lbid.

${ }^{123}$ Michael Taylor, 'Factbox: Indonesian Palm Oil Sector's Vital Statistics', Reuters (online), 15 July 2012 <http://uk.reuters.com/article/2012/07/15/uk-indonesia-palmoil-idUKBRE86E0HC20120715>.

${ }^{124}$ Manginar Situmorang, 'Strengthening the Peasant and Plantation Workers' Movement in Northern Sumatra', Asia Monitor Resource Centre, 16 November 2010 <http://www.amrc.org.hk/node/1005>

125 Ibid.

${ }^{126}$ Krystof Obidzinski, Rubeta Adriani, Heru Komarudin and Agus Andrianto, 'Environmental and Social Impacts of Oil Palm Plantations and Their Implications for Biofuel Production in Indonesia' (2012) 17(1) Ecology and Sociology 10.
} 
growers, who are usually migrant skilled labourers with prior exposure to palm oil production. ${ }^{127}$ Evidently, for the average unskilled plantation worker in Indonesia, their economic incentive to continue working for the plantation is low. It is likely that with provision of reasonable financial aid, the workers would be willing to move elsewhere for work.

A second way that workers could be involved in the buy-out scheme is by allowing the workers to buy into the transition of land from palm oil production to conserved peat and forestlands. By allowing the locals to become stewards of the lands by investing in the carbon value of the land and the possible revenue from forest materials, there is incentive for rural workers to return to their original, forest-based livelihoods. In the past, when smallholders invested in the palm oil industry, they typically acquired 2-3 ha of land on which to cultivate oil palms at a cost of a US\$3000-6000 loan from the parent firm, with 30 per cent interest due each year. ${ }^{128}$ Oil palms take 3-4 years to bear fruit, and an average income for smallholders producing palm oil is approximately US\$682-900 per month. ${ }^{129}$ With high start-up costs and high interest payments, combined with a delayed, low level of income, the result was that many smallholders remained in debt to palm oil companies for a long period of time. Because the restructuring of land use to forest conservation would result in a similar lack of immeimmediate economic gain, the buy-in mechanisms for local forest stewardship could resemble the small-holder mechanisms within the palm oil industry.

The re-wetting of peat is also an important aspect of an Indonesian buy-out scheme. Essentially, the water level must be raised to, or above, the soil level by filling or blocking ditches that divert water away from the lands, and ensuring that, instead, water is brought to the lands. A study of peatland restoration in Finland revealed that the success of peatland restoration is dependent upon site fertility and the presence of nutrients in the soil, but that damage to many interior peatlands is irreversible because only the water level near exterior peatlands can be restored by ditch filling. ${ }^{130}$ More research is needed to determine optimal restoration capacity of peatlands, and which restoration methods are most successful, depending upon local site characteristics. One method of peatland management is the practice of paludiculture, or land management techniques that cultivate biomass from restored peatlands. ${ }^{131}$ Although paludiculture is a method of sustainable agriculture that could relieve food insecurity in rural communities, it has not yet been developed in Southeast Asia despite numerous successful trials that replanted non-timber forest product producing trees on restored peatlands. ${ }^{132}$ This is likely because peatlands sequester more carbon than forests, but do not have as much value in terms of provision of basic goods for subsistence, wood products, or as a source of income from forestrelated activities.

The ideal final scenario for peatland restoration is that the value of the carbon sequestered in the lands is incorporated into an international carbon credits market. Forest carbon values are based on initial forest carbon plus carbon uptake over the period of conservation. Carbon rights to the land are sold to private investors, who then sell carbon credits on international markets to companies looking to offset their emissions. One of the challenges of establishing such a market in Indonesia is that there are many unresolved 'carbon rights' questions including who can claim the right to cause carbon emissions (can palm oil plantations?), who can claim the right to receive payments from carbon abatement, and who will measure and verify carbon stocks. ${ }^{133}$ These carbon rights, interacting with already-complicated property rights in Indonesia, must be resolved in a uniform way on the national level. A study done in Central Kalimantan indicates that the value of carbon credits from a 1000 ha area would be worth US\$6.32-8.02 million, which would be greater than the net income from a palm oil plantation. ${ }^{134}$ However, other studies continue to demonstrate that the initial costs of reducing emissions from deforestation and forest degradation are great, and the lands would not immediately be restored to carbon levels that would make them competitive with profits from palm oil production. A study carried out in the pilot province of Central Sulawesi found that annual costs for each ton of carbon dioxide emissions avoided would be approximately US\$14 if the land were conserved instead of used for palm oil plan-

\footnotetext{
127 Ibid.

${ }^{128}$ Butler, above n 27

129 Ibid.

${ }^{130}$ Eeva-Stiina Tuittila, Harri Vasander and Jukka Laine, 'Impact of Rewetting on the Vegetation of a Cut-Away Peatlands' (2000) 3 (2) Applied Vegetation Science 210.

${ }^{131}$ Peatlands - Guidance for Climate Change Mitigation Through Conservation, Rehabilitation and Sustainable Use, Mitigation of Climate Change in Agriculture Programme (Food and Agriculture Organization of the United Nations and Wetlands International, October 2012) 14.

132 Ibid.

${ }^{133}$ G Galudra et al, 'Hot Spots of Confusion: Contested Policies and Competing Carbon Claims in the Peatlands of Central Kalimantan, Indonesia' (2011) 13(4) International Forestry Review 433.

134 Hemanath Swarna Nantha and Clem Tisdell, 'The Orangutan-Oil Palm Conflict: Economic Constraints and Opportunities for Conservation', (2009)18 Biodiversity Conservation 496.
} 
tations. ${ }^{135}$ Similar studies estimate costs to vary greatly, ranging from US\$5 billion per year to protect forests in the eight countries responsible for 70 per cent of global emissions to US\$33 billion per year for a total cost of a 50 per cent global reduction in carbon dioxide emissions. ${ }^{136}$ This range in costs is based upon the net present value of restored peatlands at any point in time, determined by the carbon credit value assigned by the market. For example, on the Chicago Climate Exchange in 2006, voluntary emissions reductions were worth US\$3.50 per ton, and within the 2006 EU Emissions Trading System, credits were worth US\$22.12 per ton. ${ }^{137}$ For a comparison of net present value between the revenue from palm oil production and peatlands restored for carbon offset markets, see Figure $5 .{ }^{138}$ One way to increase the price of carbon credits, or the value of the carbon stored, may be to tie carbon credits to the value of biodiversity conservation and protection of endangered species. Also, once the lands have been restored and carbon stocks are at their optimal levels, practicing sustainable forestry will produce timber revenue and employment opportunities for local communities, as well as the emissions reductions desired.

\section{Net present value: Oil palm plantation vs. Peat forest in Indonesia} Income from palm oil production vs. land preserved for carbon offsets

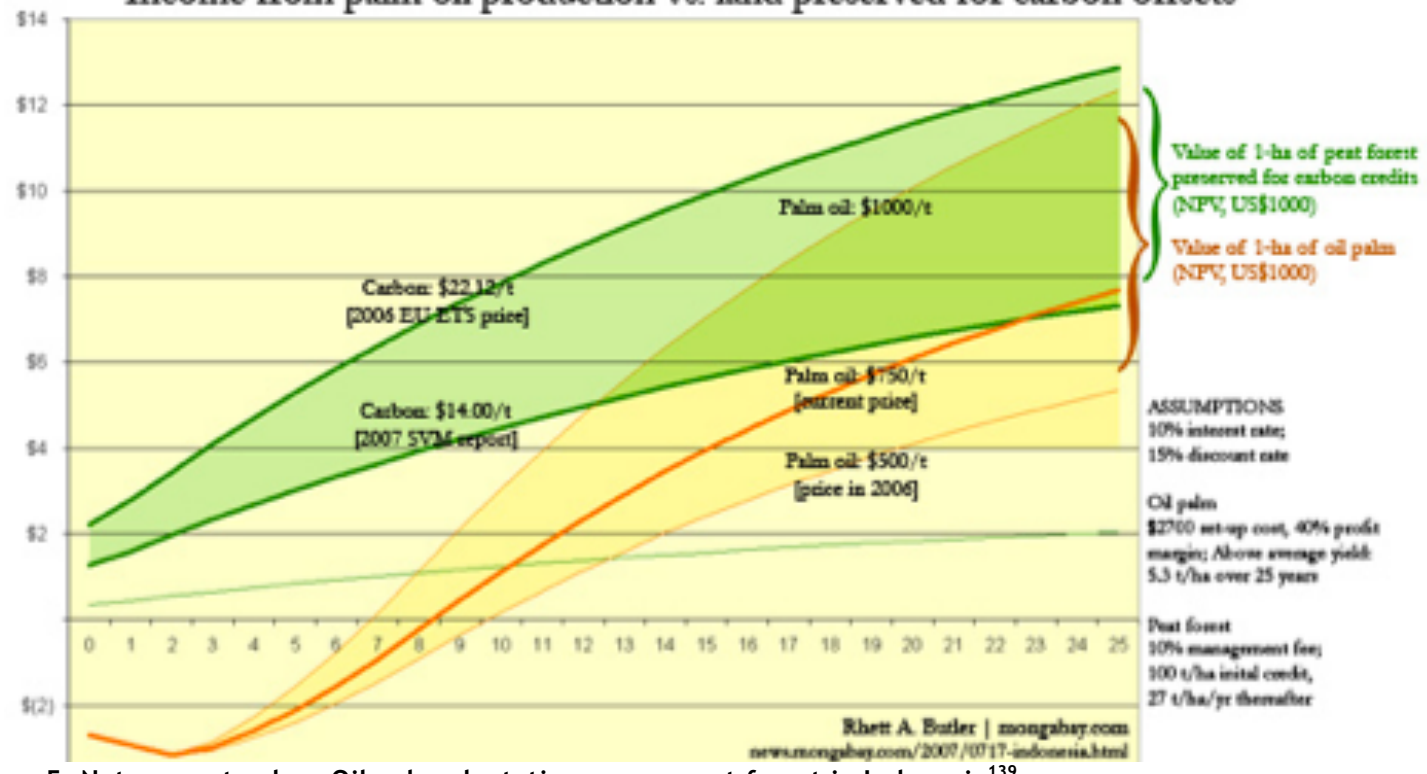

Figure 5: Net present value: Oil palm plantation versus peat forest in Indonesia ${ }^{139}$

Net present value (NPV) of 1000-ha (2500-acre) peat swamp vs oil palm plantation. Chart shows the effect of palm oil at various prices and various carbon trading schemes. Assumptions: $15 \%$ discount $/ 10 \%$ interest rate; Year $1: 100$ tons of $\mathrm{C} / \mathrm{ha}, 27$ tons of $\mathrm{C} / \mathrm{ha}(=100 \mathrm{tCO} \mathrm{e} / \mathrm{ha})$ in years thereafter; medium average palm oil yield of 5.3 tons per hectare per year over the 25 year period.

\section{Impacts of a successful peatland restoration program}

The establishment of a successful peatland restoration program in Indonesia would have vast implications for the palm oil industry and the Indonesian economy, environmental footprint and rural communities. From the economics of carbon credits discussed above, it is clear that large amounts of international funding will be necessary to make it economically preferable for Indonesia to sequester carbon instead of produce palm oil on their forested lands. While the international funds will ensure that Indonesia is not paying for the land conservation themselves, the impact on the palm oil industry will alter the growth and development patterns of the Indonesian economy. In 2008, 4,630,000 ha of Indonesia's small-holder agriculture and industrial plantations were located on peatlands. ${ }^{140}$ Although these include rice and cacao plantations as well as palm oil plantations, for the simplicity of the calculation, they will all be assumed to be palm oil plantation lands. This means that the impact upon the palm oil industry will be higher than the likely accurate impact. As stated previously, the palm oil industry has 8.4 million ha of palm oil plantations in Indonesia and exported over US\$14.5 billion in

\footnotetext{
135 Opportunity Costs of Major Land Uses in Central Sulawesi, above n 1, 20.

${ }^{136}$ Brent Swallow et al, 'Opportunities for Avoided Deforestation with Sustainable Benefits' (Interim Report, Nairobi, Kenya: ASB Partnership for the Tropical Forest Margins, November 2007) 2.

${ }^{137}$ Rhett Butler, 'Is Peat Swamp Worth More Than Palm Oil Plantations?' MongaBay.com (online), 16 July 2007

<http://news.mongabay.com/2007/0717-indonesia.html>.

138 Ibid.

139 Ibid.

${ }^{140}$ Iwan Wibisono et al, 'Peatlands in Indonesia's REDD+ Strategy' (Wetlands International, v 2, 2011), 2

<http: / / www. wetlands.org/LinkClick.aspx?fileticket=9Nesl6BCl1U\%3d\&tabid=56>.
} 
palm oil related products. If all the peatlands being used for palm oil production (4.63 million ha) are restored to their natural condition, the palm oil industry will only produce on 3.77 million ha. Thus, they will see their export revenues decrease by 55 per cent, resulting in export revenues of approximately US\$6.5 billion. This calculation assumes that the palm oil industry will not develop on alternative lands in response to the peatland buy-back. In 2009, the palm oil industry contributed 4.5 per cent to the national Gross Domestic Product (GDP) of Indonesia. ${ }^{141}$ If ha available for palm oil production have been decreased by 55 per cent, the industry's contribution to the GDP will be approximately 2 per cent.

Between 1990 and 2008, Indonesia's peatland carbon emissions increased from 193 metric tons to 498 metric tons. ${ }^{142}$ Of the 305 metric ton increased over the two decades, 246 metric tons of the emissions were from industrial plantations and small-holder agriculture. ${ }^{143}$ For the sake of the calculation, industrial plantations and small-holder agriculture will all be assumed to be palm oil related activities, as in the revenue calculation above. Thus, if the increase in emissions from palm oil production were ceased, and the peatlands were restored so that emissions from continuous oxidation of degraded peatlands were halted, despite a 158 per cent increase in emissions between 1990 and 2008, Indonesia would display a 50 per cent decrease in emissions from the buy-out scheme.

The impact on rural communities of a peatlands restoration from palm oil plantations to natural habitat will have both positive and negative consequences. As discussed earlier in the paper, there are negative environmental effects of palm oil production other than greenhouse gas emissions, such as water pollution. These environmental effects are primarily felt by those communities living near the plantations, so a restoration of natural habitat would greatly reduce air and water pollution, soil erosion and pesticide run-off in nearby rural communities. Also previously discussed, the economic impacts of palm oil plantations are only positive if the local residents are small-holders (and even in this case, there is often long-term debt). For the average, unskilled Indonesian worker, the wages paid for working on a palm oil plantation are below the poverty line. Although the palm oil industry has brought infrastructure and education opportunities to rural communities, the palm oil industry has been able to exploit local workers, paying them very little and providing very little job security. It is difficult to gauge exactly how the palm oil industry workers will be reabsorbed into the working population in Indonesia. ${ }^{144}$

\section{Conclusions}

The time to act on climate change is now: as GHG rise drastically in the name of economic development in developing countries such as Indonesia, policy programs to curb climate change and protect our global environment are desperately needed. Indonesia has the greatest biodiversity of any country and some of the most important peatlands for carbon sequestration in the world, but they are being destroyed at an alarming rate to make room for palm oil plantations. Within the last couple years, Indonesia's leaders have expressed a desire to reduce emissions, and Indonesia established a UN-REDD Programme and began a REDD+ partnership with Norway. Despite the initiatives and policies established, in practice deforestation has continued by means of corruption, legal loopholes in laws and contracts, and weak rule of law. Thus, a strategic overhaul is necessary, and two such options exist. Trade pressure by means of a ban or low quota could be exerted from primary palm oil importing countries India, China and the EU that would force Indonesian palm oil plantations either out of business or into sustainable business practices. However, given that palm oil is a cheap commodity with a multitude of different uses, it would be difficult to successfully cut demand drastically enough to impact Indonesia's production levels and conservation efforts.

Executing a buy-out scheme funded by international powers and promoted as a domestic policy campaign seeking to preserve Indonesian forests' biodiversity based upon religious principles as well as Indonesia's commitment to the CBD and UNESCO, is the preferred alternative to the ineffective REDD+ policies. The Scotland peat restoration program serves as a successful example of peatland restoration and should promote international funding participation in Indonesia's effort. While the international funds could be used to simply buy back the lands from the palm oil industry, this is not the most economical way to acquire the land. Instead, the government should levy a high tax on using peatlands for palm oil production, making that land use

\footnotetext{
141 'Indonesia's Palm Oil Contributes 4.5 pct to GDP', iStockAnalyst (online), 24 November 2009 <http://www.istockanalyst.com/article/viewiStockNews/articleid/3660667>.

${ }^{142}$ Wibisono et al, above $\mathrm{n} 140,13$.

143 lbid.

144 I have contacted Mas Achmad Santosa, the Chair of Indonesia's REDD+ Task Force's Legal Review and Law Enforcement Working Group, to learn more about the impacts of a buy-out scheme on the plantation workers.
} 
no longer as economically profitable. The government can then acquire the lands, and international funds can be put towards providing financial assistance for either worker relocations or re-wetting of the peat. Ideally, as the peatlands recover their carbon content, the lands can be made profitable according to their carbon value, and land managers can sell carbon credits on the international market to ensure the land's continuous conservation. Various pricings of carbon credits within studies have resulted in varied predictions of costs and revenues associated with peatland participation in global carbon markets. Whether or not the economic successes of peatland conservation are seen in the establishment of a carbon market, there are other impacts of a buy-out scheme. The palm oil industry, assuming that it does not move production to other lands, will face a production decrease of over 50 per cent, and the GDP input of the palm oil industry will be cut in half. The environmental impacts of peatland restoration and removal of palm oil plantations are, of course, positive. The impacts on local communities are a mix of positive impacts, such as a decrease in exploitation of unskilled workers, and negative impacts, such as a decreased infrastructure investment in rural communities.

In sum, the possibility to mitigate climate change and reduce GHG emissions, by means of international funds and promoted by an educational biodiversity preservation campaign, is a chance for Indonesia to take responsibility for its deforestation. Indonesia's peatlands have a global importance that dictates that initiatives ought to be undertaken to ensure their preservation. While the buy-out scheme necessitates that taxation mechanisms are successfully enforced, instead of broken down by corruption and weak rule of law, the capacity for both economic profits and environmental conservation by way of engagement in a carbon market make a buyout scheme for peatland restoration unquestionably the preferred alternative to current REDD+ policies. 